\title{
合板と鋼材によるサンドイッチ AN EXPERIMENTAL STUDY ON パネルの圧縮耐荷機構に関わる COMPRESSION RESISTANT 実験的研究 \\ MECHANISM OF SANDWICHED PANEL OF STRUCTURAL PLYWOOD AND STEEL MEMBER
}

\section{Wataru KAMBE $-* 2$} Sumiya TAKAHASHI $-* 4$

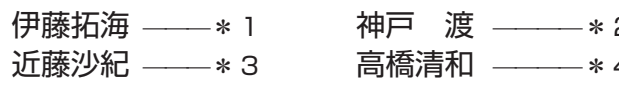

キーワード :

合成部材，合板，鋼部材，圧縮載荷試験

Keywords:

Composite structural member, Plywood, Steel member, Compression test

1.はじめに

近年，構造用合板や厚物合板が構造部材として広く利用されるよ うになってきており，建築構造分野においても様々な利用方法が提 案されている。また, 建築分野の木材需要の問題として, 安価な外 国産の木材利用に押されて，国産材の需要が少ないという問題があ る。そこで，国産間伐材の新需要を開拓し，有効利用を促進するた めの試みが様々な分野で図られている。この問題の解決策の一つと して「公共建築物等における木材の利用の促進に関する法律」 ${ }^{1)}$ 施行され，公共建築物一の利用拡大が期待されている。

著者らは，需要拡大が期待されている厚物合板と，鋼部材を合わ せた合成部材の開発を行っている ${ }^{2), 3)}$ 。厚物合板は，「住宅の品質確 保促進等に関する法律」で要求されている高い床倍率の仕様におい ても用いられるものであり，その強度は鋼部材に対する補剛材とし ての効果が期待できる。この点を利用して，鋼部材の補剛効果に期 待して合板を使用した，新しい合成部材の開発を目指している。

ここで，既往の研究において，木材と鋼材を用いた様々な合成部 材が提案されている。坂田ら ${ }^{4}$ は, シアリングや摩擦接合型コネク 夕を用いた接合方法を提案している。高木ら ${ }^{5)}$ は, トルシア型高力 ボルトを用いて木質材料と鋼材を一体化させる方法を提案している。 中島ら ${ }^{6}$ は，スリット入り薄鋼板を，木パネルでサンドイッチ寸る ことで面外変形を抑制し，エネルギー消費量を大幅に増加させたダ ンパーを提案している。

これに対して本研究では，図 1 に示すように，鋼部材または鋼材 フレームを，合板でサンドイッチした合成部材を提案し，その構造
性能を把握することを目的としている。本工法では，ボルトを手締 めにて接合することで, 施工時のトルク管理を不要とし, またリラ クセーションなどの問題が生じない。さらに, 経年劣化した合板を 容易に交換することができる点も本工法の特徴である。

例えば，この合成部材の鉄骨造建物への適用例を図 2 に示寸。同 図のように，壁要素として使用寸る方法を想定している。建物に作 用する鉛直荷重や水平荷重は，周辺架構の鋼梁を介して鋼材フレー ムに伝達される。さらに, 鋼材フレームの変形性状に応じて, ボル 卜を介して合板に力が伝達されると考えられる。このとき，合板は 鋼材フレームに対する補剛材として寄与することが期待される。

そこで本研究では，この合成部材がこれらの力を受けた場合の耐 荷機構と構造性能を明らかにすることを目的としている。本稿では, この合成部材に鉛直力が作用した場合を想定して，圧縮載荷試験を 行ったので，その結果について示す。さらに実験結果に基づき，こ の合成部材の圧縮而荷機構を明らかにする。

\section{2. 鋼部材を合板でサンドイッチした合成部材の概要}

図 1 のように，鋼部材または鋼材フレームを合板で挟み込み，予 め設けておいた孔にボルトを差し込んで手締めで接合するものであ る。ボルト接合を手締めとすることで，施工管理を容易とし，合板 の着脱が容易なシステムとなる。

この合成部材の構造性能に影響を与える変数として，鋼部材また は鋼材フレームの断面寸法と形状，ボル卜孔のクリアランス，ボル 卜の本数と配置, 合板と鋼部材の接触面の状態,などが挙げられる。
本稿は，文献 2), 3) を再構成し，加筆・修正したものである。

東京理科大学工学部第一部建築学科 講師

(厂 102-0073 千代田区九段北 1-14-6)

東京理科大学工学部第一部建築学科 助教

東京理科大学大学院工学研究科建築学専攻 大学院生

東京理科大学工学部第一部建築学科 学部生
Lecturer, Faculty of Engineering, Dept. of Architecture, Tokyo Univ. of Science

2 Assistant Prof., Faculty of Engineering, Dept. of Architecture, Tokyo Univ. of Science

Graduate Student, Graduate School of Engineering, Dept. of Architecture, Tokyo Univ. of Science

4 Undergraduate Student, Faculty of Engineering, Dept. of Architecture, Tokyo Univ. of Science 


\section{3. 圧縮載荷試験の概要}

\section{1 試験体の構成と使用部材の機械的性質}

本稿では，合成部材の圧縮載荷時の構造性能を把握することを目 的としている。ここでは, 実験スペースなどを勘案して, 鋼材フレ 一ムの鉛直部材のみを対象とし，圧縮載荷時の合板による補剛効果 に着目して検討する。そこで本稿では, 図 3 に示すような試験体を 実験対象とする。なお，合板の板厚と幅を実験変数とする。

鋼部材は, 長さ $1,500 \mathrm{~mm}$ とし, 断面 $32 \mathrm{~mm} \times 80 \mathrm{~mm}$ の中実矩形断 面（鋼種 SS400）である。後述する実験条件から，鋼部材の細長比 は 183 である。なお，鋼部材については，同一ロッドからのものを 使用することができなかったため, 以降では鋼材 1 , 鋼材 2 と示し

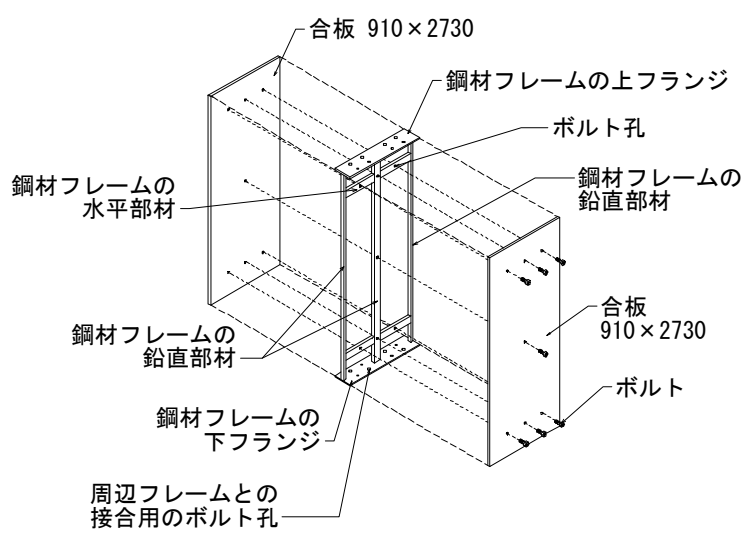

図 1 合板で鋼部材をサンドイッチした合成部材の概要

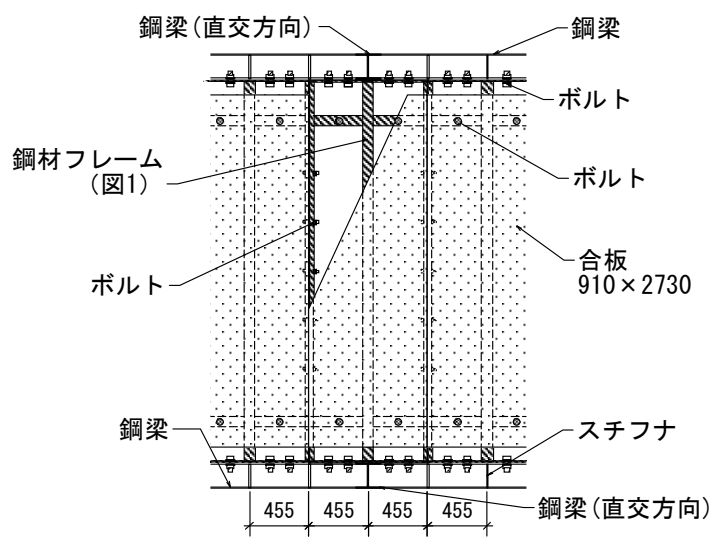

(a) 立面図

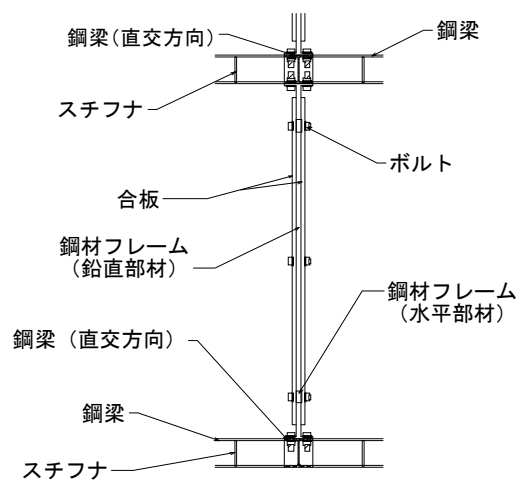

(b) 断面図

図 2 建物への適用例
ている。合板は, 長さ $1,300 \mathrm{~mm}$ とし, 板厚 $12,24,28 \mathrm{~mm} の 3$ 種類, 幅 $80,240,400 \mathrm{~mm}$ の 3 種類を用いた。なお，部材の初期不整につい て，鋼部材に有害な変形が生じていないことを目視により確認して いる。ただし，元たわみを実測していないため，本稿ではその影響 についての検討は行わない。

合板と鋼部材は，図 3 に示寸ように合板の上下端よりそれぞれ $100 \mathrm{~mm}$ の位置で，ボルト（強度区分 10.9，M16）を手締めして接合 している。なお，ボルト孔径は，合板 $18 \mathrm{~mm}$, 鋼部材 $17 \mathrm{~mm}$ とした。 試験体一覧を表 1 に示す。

ここで，上記の試験体寸法や細長比に対して，実際の建物へ適用 した際，接合部や架構形式などにより本稿の条件と対応しない可能 性も考えられる。これに関して，合板の細長比をパラメータとした 而圧縮性能に関する検討を別途行っており，試験体長さなどの寸法 効果が与える影響については別報にて報告する予定である。

鋼部材の機械的性質を表 2 に示す。鋼部材の降伏強さと引張強さ はミルシートの值，ヤング係数は次節の圧縮試験方法で行った弾性 範囲の圧縮試験結果より得た值，降伏ひずみは降伏強さをヤング係 数で除して求めた。なお, 鋼部材の限界細長比は, 鋼材 1 が 120 , 鋼材 2 が 111 となる。

合板の機械的性質を表 3 に示寸。合板の機械的性質に関して, JAS の材料実験方法に準拠すると，寸法の制約から曲げ試験の実験が困 難であったため, 広葉樹合板の試験方法に準拠して行った。降伏ひ ずみは，材料試験より得られた応力ひずみ関係より，線形関係を示 す領域として，曲げ強さの 0.4 倍の時点のひずみとした。

\section{2 試験体のセットアップと載荷方向}

試験体のセットアップ図を図 4 に示す。同図のように, 両端にナ イフエッジを設けて両端ピン支持状態とし, 単調圧縮載荷試験によ り行った。なお，上下端のピン間距離は $1,700 \mathrm{~mm}$ である。ナイフエ

表 1 試験体リストと使用鋼材

\begin{tabular}{|c|c|c|c|}
\hline \multirow{2}{*}{ 板厚 } & \multicolumn{3}{|c|}{ 合板の幅 } \\
\cline { 2 - 4 } & $80 \mathrm{~mm}$ & $240 \mathrm{~mm}$ & $400 \mathrm{~mm}$ \\
\hline \multirow{2}{*}{$24 \mathrm{~mm}$} & $\begin{array}{c}\mathrm{t} 12-\mathrm{w} 80 \\
\text { (鋼材 1) }\end{array}$ & $\begin{array}{c}\mathrm{t} 12-\mathrm{w} 240 \\
\text { (鋼材 2) }\end{array}$ & $\begin{array}{r}\mathrm{t} 12-\mathrm{w} 400 \\
\text { (鋼材 2) }\end{array}$ \\
\hline & $\mathrm{t} 24-\mathrm{w} 80$ & $\mathrm{t} 24-\mathrm{w} 240$ & $\mathrm{t} 24-\mathrm{w} 400$ \\
& $($ 鋼材 2) & (鋼材 2) & 鋼材 2) \\
\hline \multirow{2}{*}{$28 \mathrm{~mm}$} & $\mathrm{t} 28-\mathrm{w} 80$ & $\mathrm{t} 28-\mathrm{w} 240$ & $\mathrm{t} 28-\mathrm{w} 400$ \\
& $($ 鋼材 2) & (鋼材 2) & (鋼材 1) \\
\hline
\end{tabular}

表 2 鋼部材の機械的性質

\begin{tabular}{|c|c|c|c|c|}
\hline & $\begin{array}{c}\text { 降伏強ざ1 } \\
\left(\mathrm{N} / \mathrm{mm}^{2}\right)\end{array}$ & $\begin{array}{c}\text { 引張強さ*1 } \\
\left(\mathrm{N} / \mathrm{mm}^{2}\right)\end{array}$ & $\begin{array}{c}\text { 降伏ひずみ*2 } \\
(\mu)\end{array}$ & $\begin{array}{c}\text { ヤング係数*3 } \\
\left(\mathrm{N} / \mathrm{mm}^{2}\right)\end{array}$ \\
\hline 鋼材 1 & 251 & 429 & 1,146 & $2.19 \times 10^{5}$ \\
\hline 鋼材 2 & 271 & 431 & 1,340 & $2.02 \times 10^{5}$ \\
\hline
\end{tabular}

※1：ミルシート值，※2ヤング係数を降伏強さで除した值，※3：材料実験 による值

表 3 合板の機械的性質

\begin{tabular}{|c|c|c|c|}
\hline 板厚 & $\begin{array}{c}\text { 曲げ強さ } \\
\left(\mathrm{N} / \mathrm{mm}^{2}\right)\end{array}$ & $\begin{array}{c}\text { 降伏ひずみ } \\
(\mu)\end{array}$ & $\begin{array}{c}\text { ヤング係数 } \\
\left(\mathrm{N} / \mathrm{mm}^{2}\right)\end{array}$ \\
\hline $12 \mathrm{~mm}$ & 51.6 & 3,032 & $6.86 \times 10^{3}$ \\
\hline $24 \mathrm{~mm}$ & 38.4 & 3,173 & $4.86 \times 10^{3}$ \\
\hline $28 \mathrm{~mm}$ & 19.3 & 2,497 & $3.10 \times 10^{3}$ \\
\hline
\end{tabular}


ッジは，鋼部材が弱軸回りに曲げ変形するように用いた。鋼部材の 中央のひずみが $3,000 \mu$ に達した時点で載荷を終了し, 除荷した。

\section{3 計測計画}

計測図を図 3,4,5 にそれぞれ示す。圧縮荷重は試験機のロードセ ルより計測した。鉛直変位は図 4 に示すように, 試験機のクロスへ ッドと載荷テーブルの間に棒状変位計をセットして計測した。試験 体中央位置の水平変位を得るため, 図 4 に示すように試験体の両側 から巻き取り式変位計をセットして計測した。

鋼部材と合板のひずみを計測するため, 図 3 の位置にひずみゲー ジを貼付した。鋼部材と合板が接触する位置では，ゲージ面とリー ド線が納まるように合板に加工を施して貼付した。なお，合板の幅 $80 \mathrm{~mm}$ のケースにおいては，合板外面のひずみは計測していない。

なお，本稿で実施した実験では，合板の幅 $80 \mathrm{~mm}$ のケースでは合 板の外側にひずみゲージを貼付するスペースが無かったため, ひず

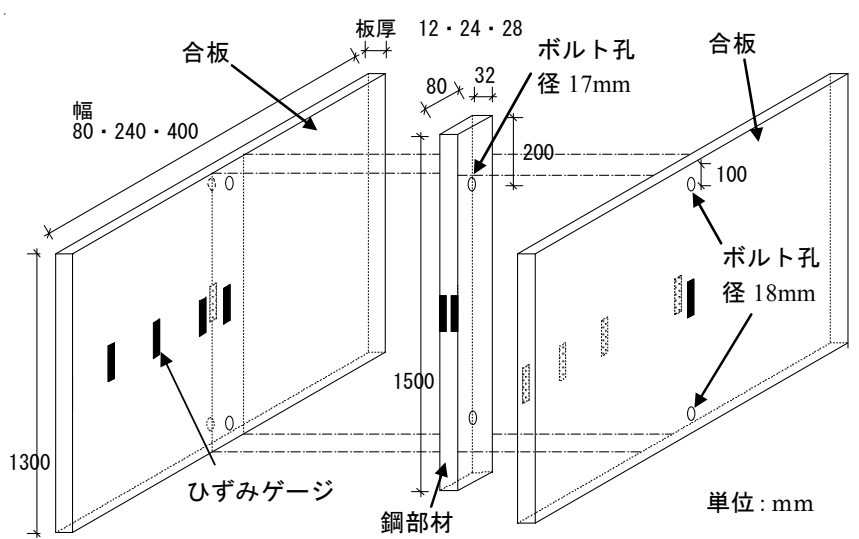

図 3 試験体の構成とひずみゲージ貼付位置

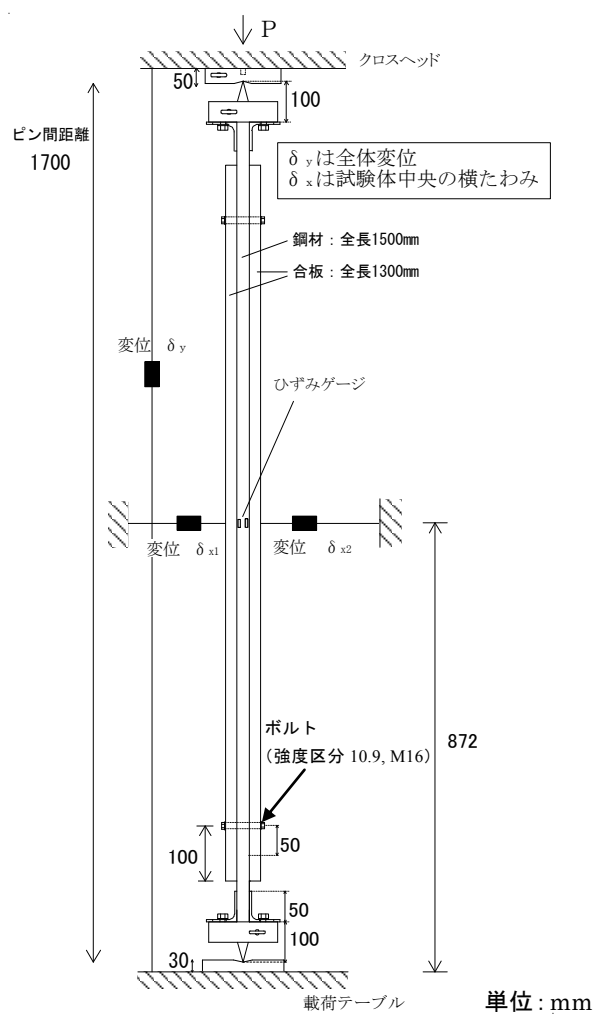

図 4 圧縮載荷試験のセットアップ図と計測図
みを計測していない。また, $\mathrm{t} 28-\mathrm{w} 400$ の実験において, 変位計設置 に不備があったため鉛直変位の計測結果が得られていない。そのた め, これらのデータに関わる実験結果は, 後述する第 4 章の結果に 示していない。

\section{4. 実験結果と考察}

\section{1 実験結果}

実験結果において, 鉛直荷重一鉛直変位関係を図 6 に示す。同図 は, 線形関係を示す領域で弾性線を引き, 横軸との交点の変位を遊 びとし, その遊びを除いて原点を合わせて示している。また, 鋼材 2 の圧縮載荷試験結果を同図に比較して示している。

合板の幅方向のひずみ分布を図 7, 断面内のひずみ分布を図 8 に 示す。図 7,8 は, 鉛直荷重が $40,80,120 \mathrm{kN}$, 最大荷重時, ならびに 最大荷重から 95\%まで荷重が低下した（以下，95\%耐力と呼ぶ）時 点の結果を示している。

部材の板厚方向の曲率と軸ひずみの関係を図 9 に示す。図 9 は, 95\%耐力点までの結果を示している。さらに, 弾性線からはずれる 時点 (比例限荷重とする), 最大荷重時と $95 \%$ 耐力時の結果を示す。

なお，図 6 では圧縮荷重を正，図 7,8では引張ひずみを正，図 9 では圧縮ひずみを正としている。

さらに, 実験結果において, 比例限荷重, 最大荷重, 鉛直剛性の 一覧を表 4 に示す。

鋼部材と合板の挙動に関して, 最大荷重以降に図 10 のような曲げ 変形の様子が確認された。同図の曲げ変形に対して, 合板を引張側 と圧縮側に区別する（以下, 引張側合板, 圧縮側合板と呼ぶ）。同図 のように，引張側合板は，鋼部材に追従して曲げ変形していた。し かし，圧縮側合板は，鋼部材に追従できず，同図に示すように隙間 が生じた試験体も観察された。

\section{2 荷重変形曲線とひずみについて}

図 6 の結果より, いずれの試験体も最大荷重を迎えたあと, 荷重 が低下する様子が確認できる。図 6 と表 4 の鉛直剛性の結果より, 鋼部材のみの鉛直剛性の計算值 $375 \mathrm{kN} / \mathrm{mm}$ に対して, 実験結果は小 さくなっており, 初期不整の影響があった可能性が考えられる。

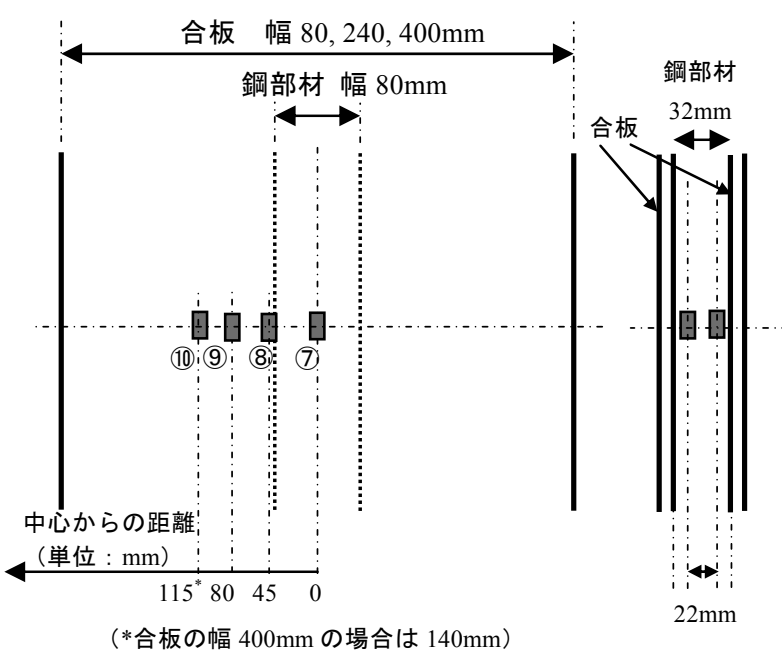

(a) 幅方向のゲージ位置

(b) 断面方向 
さらに, 図 7,8,9 の各部材のひずみより, 最大荷重時は表 2,3に 示す降伏ひずみ以下に概初留まっており, 最大荷重時までは弾性範 囲の挙動であることが確認できる。

\section{3 試験体の挙動について}

\section{3.1 合板の幅方向のひずみ分布}

図 7 の結果において, 合板の板厚が $24,28 \mathrm{~mm}$ の場合, 最大荷重 時までの幅方向のひずみ分布は概初同值を取っていることが確認で きる。このことから, 試験体中央部については, 合板は鋼部材と接 触している部分だけが変形しているのではないことが確認できる。

また, 合板の板厚が $12 \mathrm{~mm}$ の場合、引張側合板も上述と同様の傾 向を示しているが、圧縮側合板については最大荷重付近で鋼部材と 接している部分のひずみが小さく、鋼部材と接していない部分は幅 方向に概ね同值を取っていることが確認できる。

\subsection{2 断面内のひずみ分布}

図 8 の結果より, 引張側合板と鋼部材のひずみ分布の勾配につい て, 最大荷重時まで（図 8 の白抜きシンボル）は部材間で連続して おり, 試験体は一体的に挙動していることが確認できる。その後, 最大荷重時にひずみ分布が部材間で非連続となっており, 部材間で

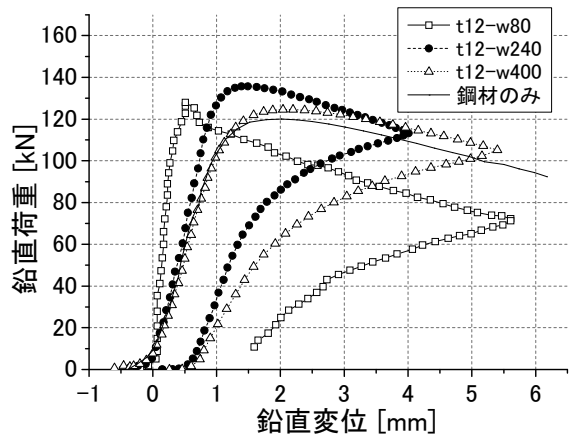

(a) 合板の板厚 $12 \mathrm{~mm}$ の場合

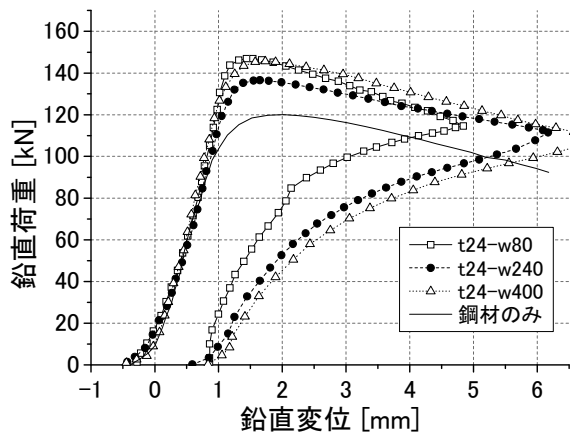

(b) 合板の板厚 $24 \mathrm{~mm}$ の場合

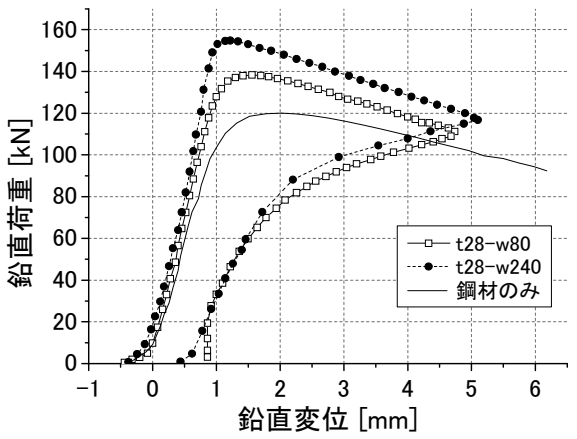

(c) 合板の板厚 $28 \mathrm{~mm}$ の場合

図 6 鉛直荷重一鉛直変位関係（圧縮を正）
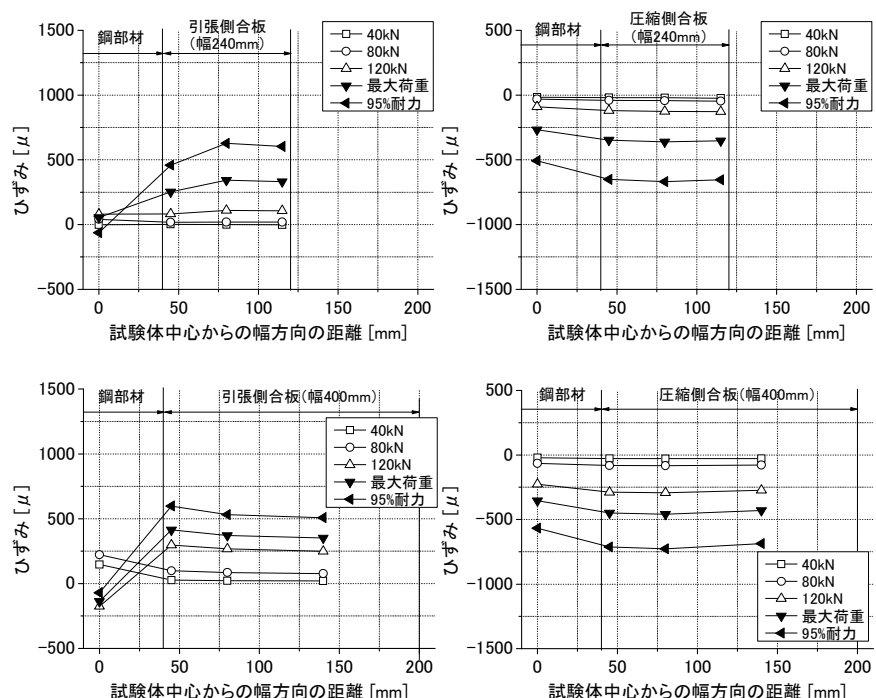

(a) 合板の板厚 $12 \mathrm{~mm}$ の場合
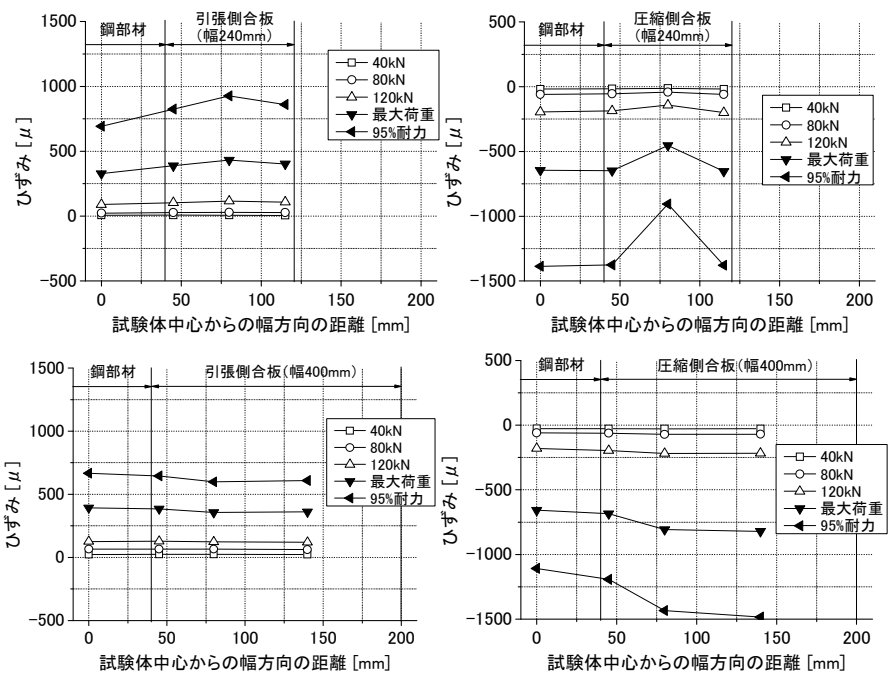

(b) 合板の板厚 $24 \mathrm{~mm}$ の場合
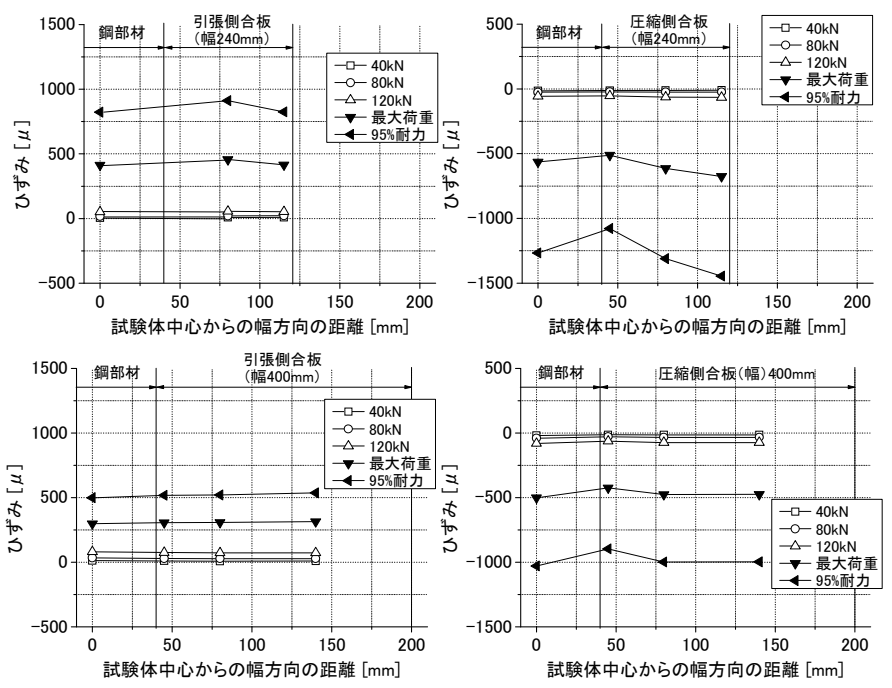

(c) 合板の板厚 $28 \mathrm{~mm}$ の場合

図 7 合板の幅方向のひずみ分布（引張を正） (左図は引張側合板，右図は圧縮側合板の結果を示す） 
ひずみが伝達されていない様子が確認できる。

\section{3.3 軸ひずみと曲率の関係}

図 9 の結果より, 比例限荷重あたりから曲率が増加しはじめ, 最 大荷重以降に曲率が急増する様子が確認できる。なお, 実験では, 最大荷重以降に試験体中央部の横たわみが生じ, 曲げ変形する様子 が観察されたが，この挙動と整合している。また，最大荷重時付近 において, 各部材の曲率は概ね同程度になっている。さらに, 合板 の軸ひずみは鋼部材と比較して非常に小さいことが確認できる。

\section{3.4 試験体の挙動について}

以上の結果を整理すると，本試験体の挙動は以下のようになる。

1) 最大荷重時までは，部材は概袮性範囲に留まっている。
2) 最大荷重付近において, 部材の曲率が増加し, 曲げ座屈によっ て最大荷重が決まる。また, 各部材の曲率は概水同程度である。

3) 最大荷重付近では, 部材間でひずみが伝達されていない。

4) 試験体中央部においては, 合板は鋼部材と接触している部分だ けが変形しているわけではない。

以上 2),3)より, 最大荷重付近では各部材の曲率が近い值になって いること，ならびに部材間でひずみが伝達されていないことから， 本試験体は，いわゆる重㸚梁 ${ }^{77}$, 8 に近い挙動（図 11）を示している ことが考えられる。ただし，合板の設置区間や接合方法の影響，ま た今回の実験結果からは，その有効な補剛区間などを明らかにする ことは困難であり, 今後詳細な検討を行う必要がある。
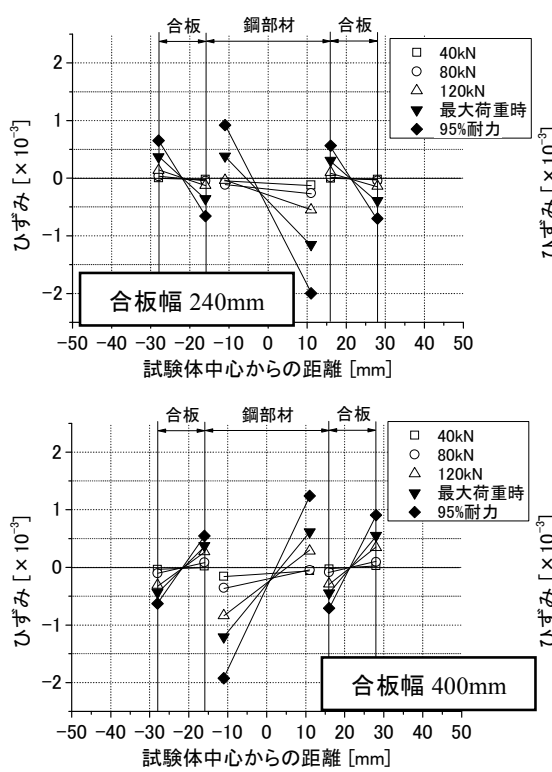

(a) 合板の板厚 $12 \mathrm{~mm}$ の場合
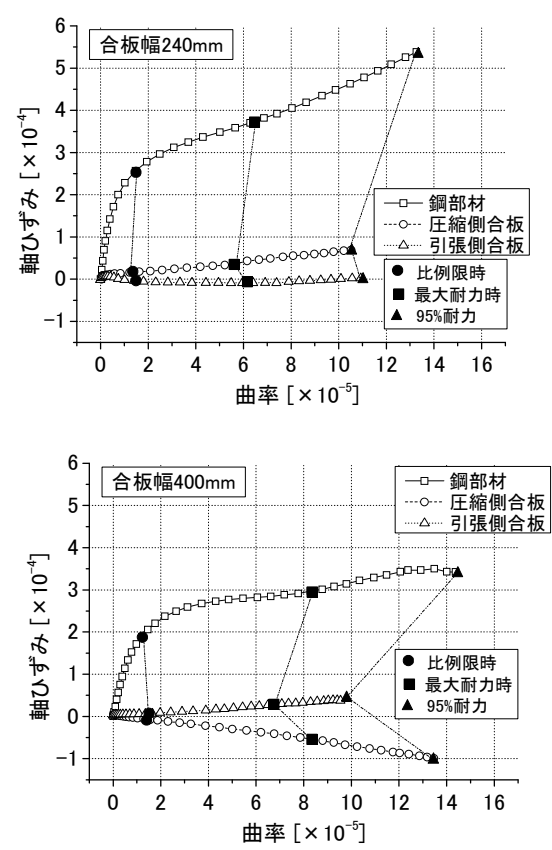

(a) 合板の板厚 $12 \mathrm{~mm}$ の場合
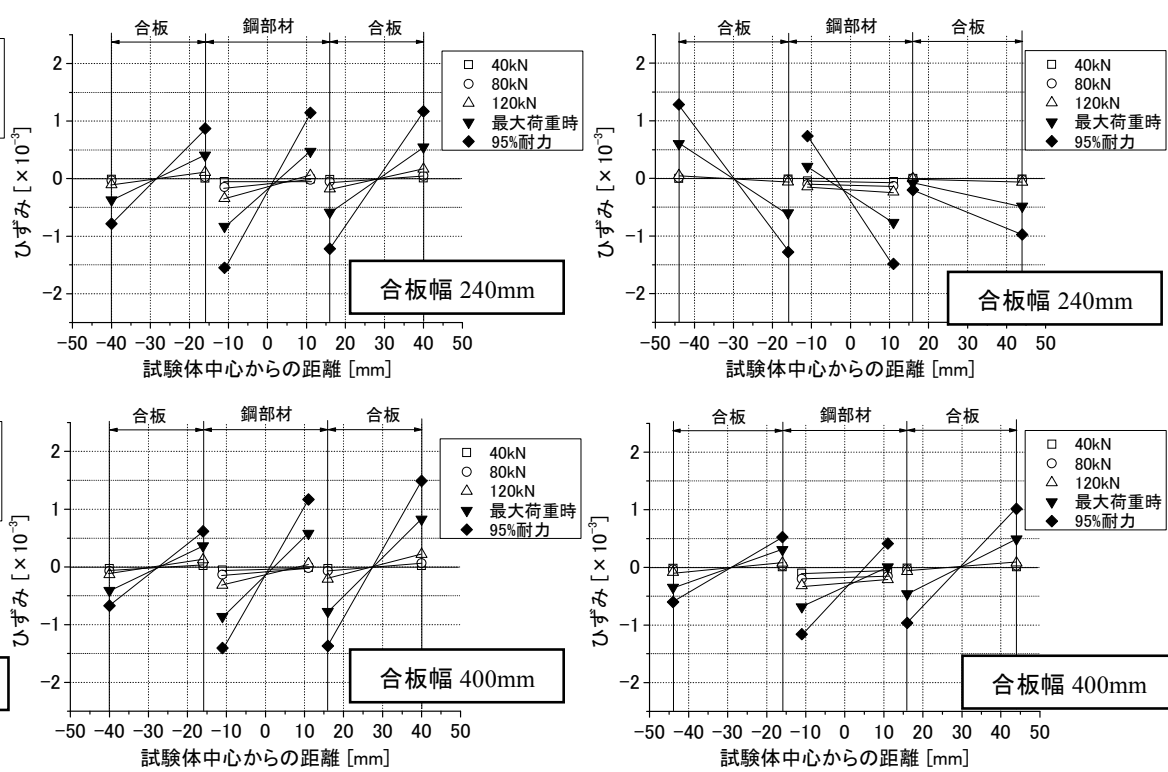

(b) 合板の板厚 $24 \mathrm{~mm}$ の場合

図 8 断面内のひずみ分布（引張を正）
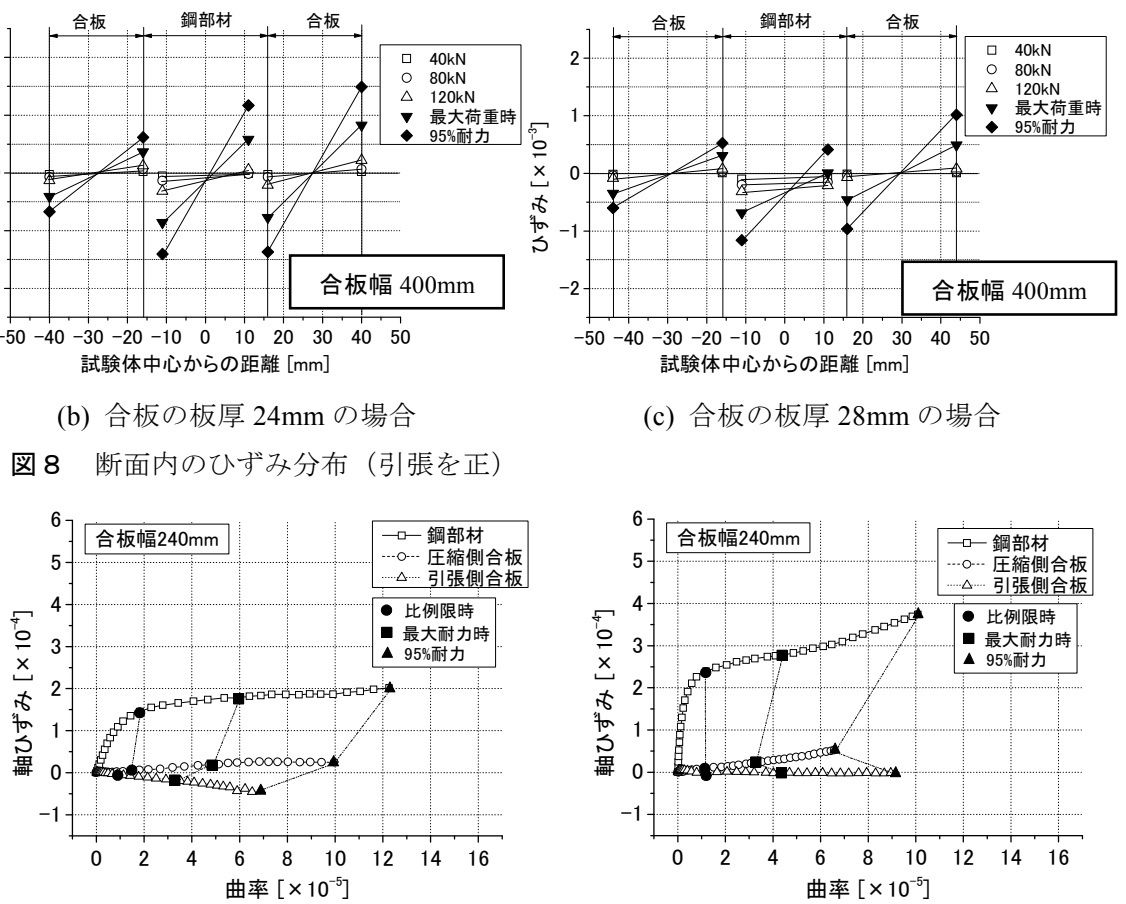

(c) 合板の板厚 $28 \mathrm{~mm}$ の場合
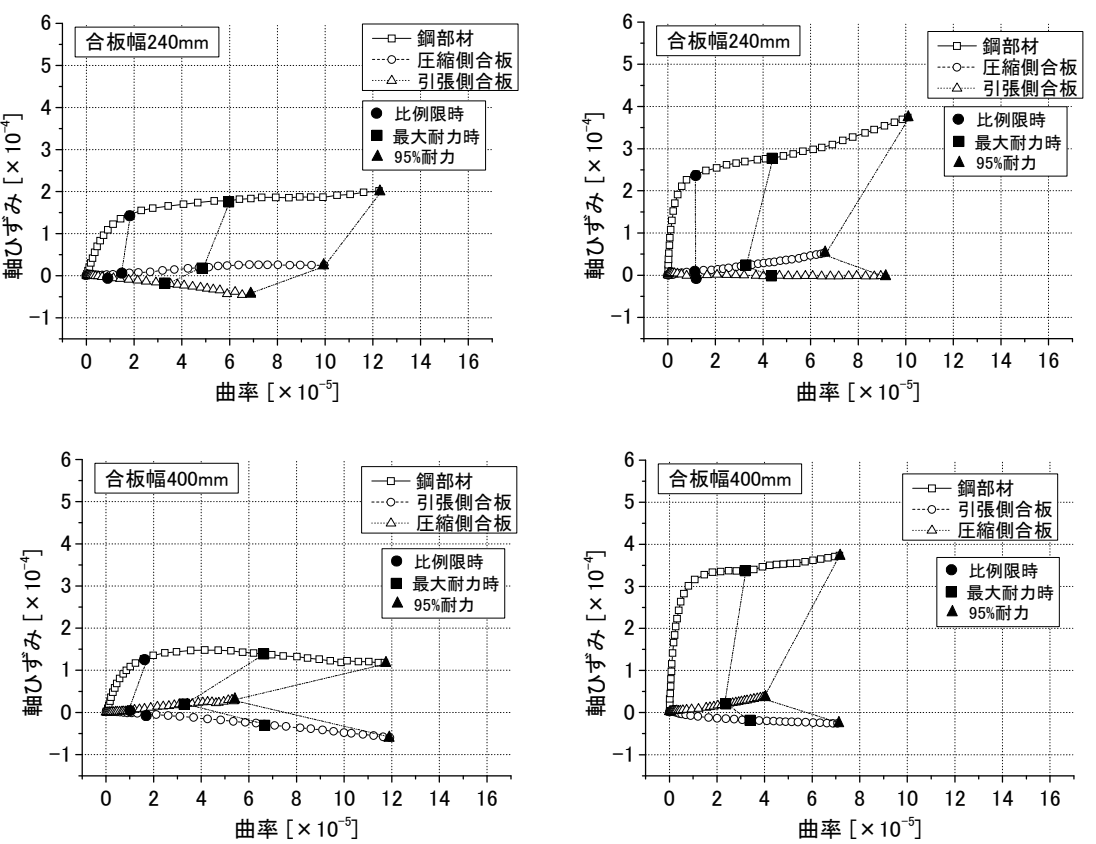

(b) 合板の板厚 $24 \mathrm{~mm}$ の場合

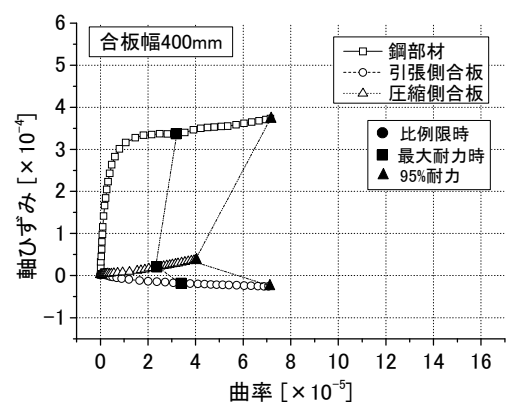

(c) 合板の板厚 $28 \mathrm{~mm}$ の場合

図 9 部材の軸ひずみと曲率の関係（軸ひずみは圧縮を正） 


\section{4 合板の寸法と最大荷重の関係}

合板の板厚と最大荷重の関係を図 12 に示す。結果として, t28-w80 を除き,合板の板厚が大きいほど最大荷重が大きくなる傾向がある。 また，幅の影響としては，有意な傾向を確認することはできない。

ここで，前節の通り，本試験体は曲げ座屈により最大荷重が決ま り, 試験体中央部では重衫梁に近い挙動を示すことから, 最大荷重

表 4 実験結果一覧

\begin{tabular}{|c|c|c|c|}
\hline 試験体名 & $\begin{array}{c}\text { 比例限荷重 } \\
(\mathrm{kN})\end{array}$ & $\begin{array}{c}\text { 最大荷重 } \\
(\mathrm{kN})\end{array}$ & $\begin{array}{c}\text { 鉛直剛性 } \\
(\mathrm{kN} / \mathrm{mm})\end{array}$ \\
\hline t12-w80 & 94.3 & 128.0 & 377.0 \\
\hline $\mathrm{t} 12-\mathrm{w} 240$ & 110.2 & 135.6 & 139.5 \\
\hline $\mathrm{t} 12-\mathrm{w} 400$ & 80.1 & 124.5 & 107.8 \\
\hline t24-w80 & 130.6 & 147.0 & 128.1 \\
\hline t24-w240 & 120.9 & 136.6 & 113.7 \\
\hline t24-w400 & 120.2 & 145.6 & 126.7 \\
\hline t28-w80 & 117.8 & 138.3 & 133.8 \\
\hline t28-w240 & 143.6 & 154.9 & 160.6 \\
\hline t28-w400 & -- & 163.6 & -- \\
\hline
\end{tabular}
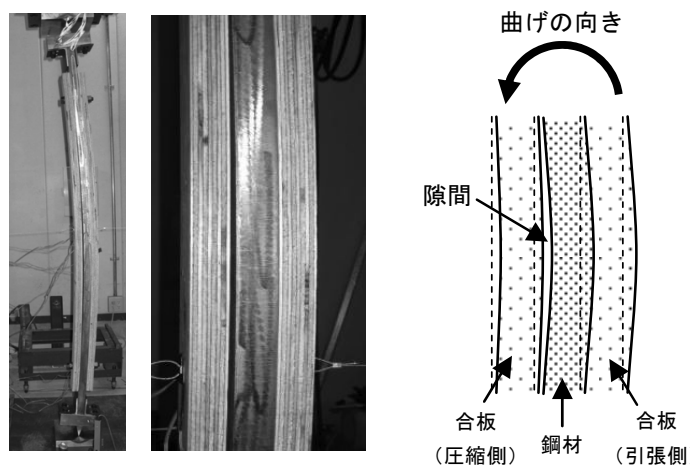

図 10 最大荷重以降の試験体の変形（t28-W80 の場合）
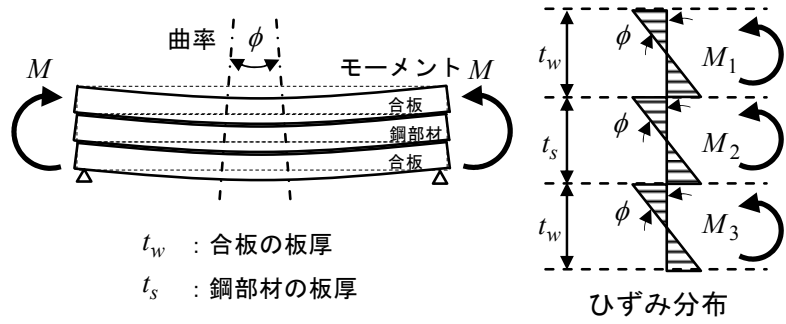

図 11 重㸚梁モデル ${ }^{7), 8)}$ に基づくひずみと曲率の分布

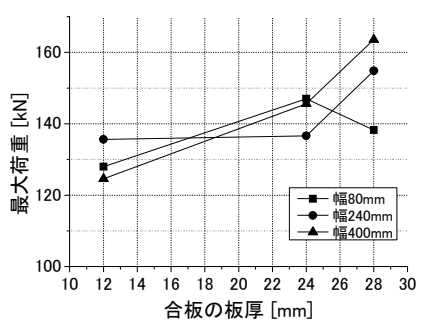

図 12 合板の板厚と最大荷重 の関係

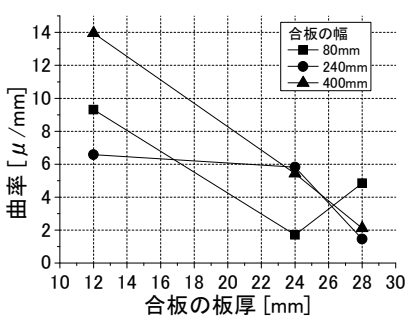

図 13 合板の板厚と鋼部材の 曲率の関係（鈆直荷重 $80 \mathrm{kN}$ 時）
は合板の板厚と幅に比例する結果になることが予想される。しかし， 合板の有効な補剛区間や詳細な抵抗機構などを明らかにし，その影 響を考慮した検討を行う必要があると考えられる。

\section{5 曲率の比較}

比例限以下の荷重 $80 \mathrm{kN}$ 時において, 合板の板厚と鋼材の曲率の 関係を図 13 に示す。結果として, t28-w80 を除き，板厚が大きいほ ど鋼材の曲率が小さくなっている。このことから，板厚が大きいほ ど曲げ剛性が大きくなり，最大荷重が大きくなったと考えられる。

\section{5. 結び}

本稿では，構造用合板または厚物合板で鋼部材を挟み込んだ合成 部材を提案し, 圧縮荷重下における挙動を明らかにするために実験 的な検討を行った。

鋼材のみの最大荷重と比較して，合板で挟み込むことで最大荷重 が大きくなる。合板の板厚が大きいほど最大荷重が大きくなるが， 合板の幅が最大荷重に与える影響は小さい。

さらに，実験結果に基づいて，試験体の挙動ならびに耐荷機構に ついて整理した。その結果として, 本稿の実験条件においては, 曲 げ座屈により最大荷重が決まり, 最大荷重時まで合板ならびに鋼部 材は概ね弾性範囲に留まる。また，最大荷重時までは，部材間でひ ずみが伝達しておらず，各部材の曲率は近い值を示す。これらの結 果より，本試験体は，いわゆる重水梁に近い挙動を示す。

以上，本稿では実験的検討を行った。今後，実験結果に基づいた 解析的検討を予定しており，結果については別報にて報告する。

\section{謝辞}

本稿の実験は, 平成 22 年度東京理科大学特定研究助成金 (研究代 表者：伊藤拓海）より助成をいただきました。また，本稿の図の作 成にあたり, 東京理科大学学部生 三富遼太君に多大なる支援をい ただきました。ここに記して謝意を表します。

\section{参考文献}

1) 例えば，林野庁編：平成 23 年版 森林・林業白書

2) 近藤沙紀, 神戸渡, 伊藤拓海 : 構造用合板と鉄骨部材によるサンドイッチ パネル構造の曲げ座屈耐力, その 1 実験概要, その 2 実験結果, 日本建 築学会関東支部研究報告集, 構造, pp.225-232, 2011.3

3) 神戸渡, 近藤沙紀，伊藤拓海：圧縮力を受ける構造用合板と鉄骨部材によ るサンドイッチパネル構造の力学的特性, その 1 試験体および実験結果 の概要, その 2 各部の挙動, 日本建築学会大会学術講演梗概集, C-1 分冊, pp.261-264, 2011.8

4) 坂田弘安, 堀井健史, 竹内徹, 中村博志 : シアリング接合部の木材繊維方 向せん断性能に関寸る実験研究，日本建築学会構造系論文集，第 627 号, pp.773-779, 2008.5

5) 遠藤俊貴, 高木次郎, 荒木慶一：トルシア形高力ボルトを用いた摩擦接合 により一体化した鋼木複合断面軸力材の曲げ特性，日本建築学会構造系論 文集，第 661 号,pp.591-598，2011.3

6) 伊藤麻衣, 坪山紀子, 中島正愛 : 木質パネルで面外補剛されたスリット入 り鋼板の耐震性能，日本建築学会構造系論文集，第 657 号，pp.2055-2061， 2010.11

7) 松井千秋 : 建築合成構造, オーム社出版, pp.67-69, 2004

8) 日本建築学会 : 木質構造接合部設計マニュアル, pp.179-191, 2010

[2012 年 2 月 14 日原稿受理 2012 年 4 月 10 日採用決定］ 